\title{
Synthesis and Evaluation of Analgesic and Antioxidant Activities of Substituted Benzimidazole Derivatives
}

\author{
Shejuti Rahman Brishty, Poushali Saha, Zobaer Al Mahmud \\ and S. M. Abdur Rahman
}

\author{
Department of Clinical Pharmacy and Pharmacology, Faculty of Pharmacy \\ University of Dhaka, Dhaka-1000, Bangladesh
}

\begin{abstract}
(Received: February 16, 2020; Accepted: June 02, 2020; Published (web): June 28, 2020)
ABSTRACT: The present study describes the synthesis and pharmacological evaluation of a number of substituted benzimidazole derivatives designated by 3A-1, 3A-2, 3A-3, 3B-1 and 3B-2 through condensation of different $o$-aryldiamine compounds with the corresponding aldehyde employing ammonium salt as a catalyst. All the compounds were characterized by IR and ${ }^{1} \mathrm{H}$ NMR spectroscopic analysis. The synthesized benzimidazole derivatives were investigated for analgesic and antioxidant activities using acetic acid-induced writhing inhibition in Swiss albino mice and DPPH free radical scavenging assay, respectively. Compounds 3A-3, 3B-1 and 3B-2 at a dose of 50 $\mathrm{mg} / \mathrm{kg}$ body weight reduced the number of writhings by $88.24 \%, 84.03 \%$ and $85.71 \%$, respectively $(\mathrm{p}<0.001)$ in comparison with standard diclofenac (90.76\% inhibition). The derivatives 3A-1, 3A-2, 3A-3 and 3B-2 showed prominent antioxidant activity with $\mathrm{IC}_{50}$ values of $0.038,0.959,8.834$ and $7.519 \mu \mathrm{g} / \mathrm{ml}$, respectively in comparison with the standard butylated hydroxytoluene (BHT) $(14.44 \mu \mathrm{g} / \mathrm{ml})$. Among the synthesized compounds, 3A-3 and 3B2 emerged as the most promising analgesic and antioxidant agents and expressed their potential as lead compounds in future research.
\end{abstract}

Key words: Synthesis, Benzimidazole, Analgesic, Antioxidant, Writhing inhibition, $\mathrm{IC}_{50}$ value.

\section{INTRODUCTION}

Heterocyclic compounds carry special significance in drug design and medicinal chemistry owing to their wide range of biological activities. A large number of heterocycles have been explored in the last few decades for developing new therapeutic and pharmaceutical agents, among which the benzimidazole derivatives have occupied a very prominent place. ${ }^{1}$ Benzimidazole nucleus, principally formed as a five-membered ring system shows notable basic characteristics because of its nitrogen content and thus forms the active substances of several commercially available drugs. Benzimidazole derivatives encompass various pharmacological activities such as antimicrobial and antibacterial ${ }^{2}$, anthelmintics (albendazole) $)^{3}$, antiviral (enviradine) ${ }^{4}$,

Correspondence to: S. M. Abdur Rahman Tel: +88(02)9661920-73, Ext. 8166 (office), +8801732477343 (mobile); Fax: +88(02)8615583

Email: smarahman@du.ac.bd

Dhaka Univ. J. Pharm. Sci. 19(1): 37-46, 2020 (June) DOI: https://doi.org/10.3329/dujps.v19i1.47817 fungicidal (carbendazim $)^{5}, \quad$ anti-neoplastic

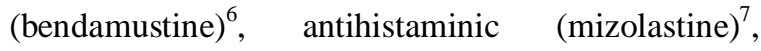
analgesic (bezitramide) ${ }^{8}$ antihypertensive (telmisartan $)^{9}$, anticoagulant (dabigratan) $)^{10}$, proton pump inhibitors (omeprazole) ${ }^{11}$ and calcium sensitizer (pimobendan). ${ }^{12,13}$ Therefore, benzimidazole moiety is considered as a 'privileged structure' in heterocyclic chemistry and has been of great interest to synthetic and medicinal chemists.

As per recent literature reviews, the substitution at the 1,2 and 5 positions of the benzimidazole ring is crucial for exhibiting numerous pharmacological activities. ${ }^{14-17}$ Specifically, 2-substituted analogs of benzimidazole are known to be potent biologically active compounds. ${ }^{18-20}$ In view of the extensive applications of benzimidazole moiety in medicinal chemistry, an attempt was made to produce a number of 2-substituted benzimidazole derivatives bearing different functional groups at various positions. A simple and easily reproducible procedure was employed involving the condensation of diamine 
compounds, specifically the derivatives of $o$-aryldiamine with the corresponding aldehydes using ammonium salts as catalysts. Recently, benzimidazole derivatives substituted at 1 and 2 positions have been found to possess prominent antioxidant activity. ${ }^{21-23}$ Moreover, benzimidazole nucleus with different functional groups attached to 1,2, 5 and 6 positions has been reported as the pharmacophore of choice for developing new molecules with analgesic and antioxidant properties. ${ }^{3,24,25}$ Encouraged by these findings published in the literature and considering the importance of synthetic drugs and medications in pain relief and management of different disease conditions, our present work was aimed to synthesize several 2-substituted benzimidazole derivatives with varied substituents at different positions of benzimidazole nucleus and explore their analgesic and antioxidant potential.

\section{MATERIALS AND METHODS}

Chemicals and reagents. All reactions were carried out in well-dried glassware using a nitrogen atmosphere. Chemicals and reagents, i.e. $o$ phenylenediamine, 2,3-diaminotoluene, anisaldehyde, chloroform, ammonium chloride, $n$-hexane, ethyl acetate, sodium sulfate, sodium chloride, acetic acid, tert-butyl-1-hydroxytoluene or simply butylated hydroxytoluene (BHT) and 2,2-diphenyl-1- picrylhydrazyl (DPPH) were obtained from SigmaAldrich, USA. $n$-hexane and ethyl acetate were distilled over calcium hydride before use. Silica gel 60 (0.06-0.2 mm, ROTH) was used for column chromatography (CC). IR spectra were recorded on a SHIMADZU FTIR-8400S spectrometer (Shimadzu Corporation, Japan).

Acquisition of spectral data and monitoring of reactions. ${ }^{1} \mathrm{H}$ NMR spectra were acquired on a JEOL Alpha 400 spectrometer $(400 \mathrm{MHz})$ using $\mathrm{CDCl}_{3}$ as solvent and tetramethylsilane (TMS) as an internal reference standard. The chemical shift $(\delta)$ values are reported in parts per million (ppm) and spin-spin coupling constants $(J)$ were expressed in Hz. To monitor the reactions, thin layer chromatography (TLC) was performed on precoated plates of silica gel (silica gel $60 \mathrm{GF}_{254}$, Sigma-Aldrich).

General procedure for the synthesis of benzimidazole derivatives. The synthetic pathway is depicted in Scheme 1. Two derivatives of $o$ aryldiamine (1) i.e. $o$-phenylenediamine (1A) and 2,3-diaminotoluene (1B) along with anisaldehyde (2) were chosen as starting materials, and ammonium chloride was selected as a catalyst for the experiment based on their commercial availability and reported toxicity profiles. The substituted benzimidazole derivatives were synthesized by modifying a method

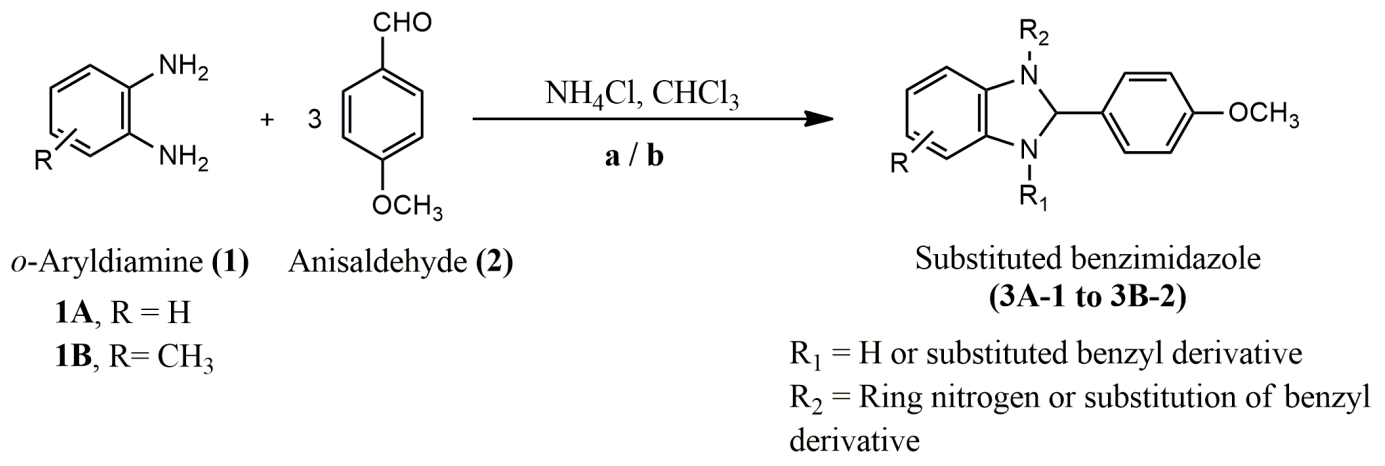

Scheme 1. Synthesis of substituted benzimidazole derivatives. a: Room temperature, $6 \mathrm{hrs} . \mathbf{b}: 40^{\circ} \mathrm{C}, 12 \mathrm{hrs}$.

previously reported in the literature. ${ }^{26}$ Initially, 1.0 equivalent of diamine compounds, 3.0 equivalents of anisaldehyde and 4.0 equivalents of ammonium chloride were taken in a round bottom flask and the resultant mixture was stirred for five min at required temperature as per the starting material (Table 1). Afterwards, $5 \mathrm{ml}$ of chloroform was added to the solution and stirring was continued for a certain hour 
in accordance with each reaction (Table 1). The completion of the reaction was monitored by TLC using $n$-hexane: ethyl acetate $(1: 1)$ as the mobile phase. The solvent was subsequently removed under reduced pressure with the help of a rotary evaporator. The resultant residue was extracted with $20 \mathrm{ml}$ of ethyl acetate and the organic layer was washed with $10 \mathrm{ml}$ of brine (sodium chloride) solution. In this way, the layers were separated and the organic layer was dried over sodium sulfate. Following the removal of the solvent under reduced pressure, the product was subjected to column chromatography using ethyl acetate and $n$-hexane in different ratios. Several compounds, designated as $\mathbf{3 A - 1}$ to $\mathbf{3 B}-\mathbf{2}$ were obtained (Table 1) which was taken for characterization using analytical tests.

Table 1. Summary of the reactions.




2-(4-Methoxyphenyl)-1H-benzimidazole (3A-1). IR $\left(\mathrm{KBr}, \mathrm{cm}^{-1}\right): 3437(\mathrm{C}-\mathrm{H}$ stretching of aromatic ring), 2963 (C-H stretching of aliphatic ring), 1631 $(\mathrm{C}=\mathrm{N}$ stretching of imidazole ring $), 1503,1452(\mathrm{C}=\mathrm{C}$ stretching of aromatic ring); ${ }^{1} \mathrm{H}$ NMR $(400 \mathrm{MHz}$, $\delta / \mathrm{ppm}): 4.10\left(s, 3 \mathrm{H}, \mathrm{OCH}_{3}\right), 6.97(d, J=8 \mathrm{~Hz}, 2 \mathrm{H})$, $7.65(s, 2 \mathrm{H}), 7.75(s, 2 \mathrm{H}), 7.85(s, 1 \mathrm{H})$; Yield: 15\%.

1-(4-Methoxybenzyl)-2-(4-methoxyphenyl)-1Hbenzimidazole (3A-2). IR $\left(\mathrm{KBr}, \mathrm{cm}^{-1}\right): 3462(\mathrm{C}-\mathrm{H}$ stretching of aromatic ring), 2964 (C-H stretching of aliphatic ring), $1608(\mathrm{C}=\mathrm{N}$ stretching of imidazole ring), 1513, $1442(\mathrm{C}=\mathrm{C}$ stretching of aromatic ring), 1244 (C-N stretching of imidazole ring), 1171 ($\left.\mathrm{OCH}_{3}\right) ;{ }^{1} \mathrm{H} \mathrm{NMR}\left(400 \mathrm{MHz}, \mathrm{CDCl}_{3}, \delta / \mathrm{ppm}\right): 3.80(s$, $\left.3 \mathrm{H}, \mathrm{OCH}_{3}\right), 3.90\left(s, 3 \mathrm{H}, \mathrm{OCH}_{3}\right), 5.40\left(s, 2 \mathrm{H},-\mathrm{CH}_{2}-\right)$, $6.85(d, J=8 \mathrm{~Hz}, 2 \mathrm{H}), 6.97(d, J=8 \mathrm{~Hz}, 2 \mathrm{H}), 7.04(d$, $J=8 \mathrm{~Hz}, 2 \mathrm{H}), 7.20(m, 2 \mathrm{H}), 7.25-7.35(m, 1 \mathrm{H}), 7.64$ ( $d, J=8 \mathrm{~Hz}, 2 \mathrm{H}), 7.85(d, J=8 \mathrm{~Hz}, 1 \mathrm{H})$; Yield: $35 \%$.

1-(4-Methoxybenzyl)-2-(4-methoxyphenyl)-3(4-methoxybenzyl)-1H-benzimidazole (3A-3). IR $\left(\mathrm{KBr}, \mathrm{cm}^{-1}\right): 3053(\mathrm{C}-\mathrm{H}$ stretching of aromatic ring), 2962 (C-H stretching of aliphatic ring), 1501, 1435 $(\mathrm{C}=\mathrm{C}$ stretching of aromatic ring), $1254 \quad(\mathrm{C}-\mathrm{N}$ stretching of imidazole ring), 1179, $1125\left(-\mathrm{OCH}_{3}\right)$; ${ }^{1} \mathrm{H}$ NMR (400 MHz, $\left.\mathrm{CDCl}_{3}, \delta / \mathrm{ppm}\right): 3.78(s, 3 \mathrm{H}$, $\left.\mathrm{OCH}_{3}\right), 3.83\left(s, 3 \mathrm{H}, \mathrm{OCH}_{3}\right), 3.88\left(s, 3 \mathrm{H}, \mathrm{OCH}_{3}\right), 5.40$ $\left(s, 2 \mathrm{H},-\mathrm{CH}_{2}-\right), 6.85(d, J=8 \mathrm{~Hz}, 2 \mathrm{H}), 6.95-7.05(m, J$ $=8 \mathrm{~Hz}, 6 \mathrm{H}), 7.20(d, J=8 \mathrm{~Hz}, 2 \mathrm{H}), 7.25-7.30(m, 2 \mathrm{H})$, $7.63(d, J=8 \mathrm{~Hz}, 3 \mathrm{H}), 7.85(d, J=8 \mathrm{~Hz}, 1 \mathrm{H}), 8.00(d$, $J=8 \mathrm{~Hz}, 1 \mathrm{H})$; Yield: $25 \%$.

\section{2-(4-Methoxyphenyl)-4-methyl-1H-benzimi-}

dazole (3B-1). IR ( $\left.\mathrm{KBr}, \mathrm{cm}^{-1}\right)$ : $3244(\mathrm{C}-\mathrm{H}$ stretching of aromatic ring), 2964 (C-H stretching of aliphatic ring), 1613 ( $\mathrm{C}=\mathrm{N}$ stretching of imidazole ring), 1511, 1480, 1467 ( $\mathrm{C}=\mathrm{C}$ stretching of aromatic ring), 1248 (C-N stretching of imidazole ring), $1171\left(-\mathrm{OCH}_{3}\right)$, $3393(-\mathrm{NH}) ;{ }^{1} \mathrm{H}$ NMR $\left(400 \mathrm{MHz}, \mathrm{CDCl}_{3}, \delta / \mathrm{ppm}\right)$ : $3.87\left(s, 3 \mathrm{H}, \mathrm{OCH}_{3}\right), 2.60\left(s, 3 \mathrm{H},-\mathrm{CH}_{3}\right), 6.95-7.05(m$, $3 \mathrm{H}), 7.25(t, J=8 \mathrm{~Hz}, 1 \mathrm{H}), 7.50(s, J=8 \mathrm{~Hz}, 1 \mathrm{H})$, 7.95-8.05 ( $d, J=8 \mathrm{~Hz}, 2 \mathrm{H})$; Yield: $40 \%$.

1-(4-Methoxybenzyl)-2-(4-methoxyphenyl)-4methyl-1H-benzimidazole (3B-2). IR $\left(\mathrm{KBr}, \mathrm{cm}^{-1}\right)$ : 3390 (C-H stretching of aromatic ring), 2964 (C-H stretching of aliphatic ring), 1261 (C-N stretching of imidazole ring), 1098, $1024\left(-\mathrm{OCH}_{3}\right) ;{ }^{1} \mathrm{H}$ NMR (400 $\left.\mathrm{MHz}, \mathrm{CDCl}_{3}, \delta / \mathrm{ppm}\right): 3.75\left(s, 3 \mathrm{H}, \mathrm{OCH}_{3}\right), 3.85(s$, $\left.3 \mathrm{H}, \mathrm{OCH}_{3}\right), 2.75\left(s, 3 \mathrm{H},-\mathrm{CH}_{3}\right), 5.35\left(s, 2 \mathrm{H},-\mathrm{CH}_{2}-\right)$, 6.70-7.60 ( $m, 11 \mathrm{H}$, aromatic); Yield: $35 \%$.

Screening for analgesic activity. The in vivo analgesic activity of the synthesized compounds was evaluated by acetic acid-induced writhing method (peripheral analgesia) using Swiss albino mice (Mus musculus). ${ }^{27,28}$

Experimental animal. Swiss albino mice of either sex (25-30 g, aged 4-5 weeks) were collected from the animal house of Jahangirnagar University, Bangladesh. They were housed in polyvinyl cages under standard environmental conditions of $25 \pm 2^{\circ} \mathrm{C}$ temperature, $65-75 \%$ relative humidity and natural (12 hrs) light and dark schedule ${ }^{29}$ in the animal house of the Institute of Nutrition and Food Science (INFS), University of Dhaka, Bangladesh, and provided with icddr,b (The International Center for Diarrheal Diseases and Research, Bangladesh) formulated rodent food and water ad libitum. As these animals were very sensitive to environmental changes, they were kept for at least 3-4 days before the test in the environment where the experiment was carried out. All ethical manners involving the use of experimental animals were maintained carefully.

Experimental design. Sixty Swiss albino mice were randomly selected and divided into twelve groups, each consisting of 5 mice. Every group received a particular treatment as shown in Table 2, i.e. control, standard, and lower and higher doses (50 and $100 \mathrm{mg} / \mathrm{kg}$ body weight, respectively) of each synthesized sample at zero hour. Each mouse was weighed properly before any treatment and the doses of the standard, control and test samples were adjusted accordingly. Analgesic agent diclofenac was chosen as standard and was given orally at a dose of $50 \mathrm{mg} / \mathrm{kg}$ body weight. To produce pain sensation, acetic acid $(0.7 \%)$ was administered intraperitoneally after $40 \mathrm{~min}$ at a dose of $0.1 \mathrm{ml} / 10 \mathrm{~g}$ of body weight to each animal of all the groups. After 5 min of its administration, the number of writhing responses or squirms was counted for each mouse for $15 \mathrm{~min}$. The responses of the sample and diclofenac 
treated groups were compared with the control group. The percentage inhibition of writhing in comparison with the control group was taken as an index of analgesia and calculated by using the following formula:
Inhibition $(\%)=[(\mathrm{Wc}-\mathrm{Wt}) \times 100)] / \mathrm{Wc}$

where $\mathrm{Wc}$ is the average number of writhing reflexes in the control group and Wt is the average number of writhing reflexes in the test group.

Table 2. Screening of peripheral analgesic activity of benzimidazole derivatives by acetic acid-induced writhing response in mice.

\begin{tabular}{|c|c|c|c|c|c|c|c|c|}
\hline \multirow{2}{*}{$\begin{array}{l}\text { Sample } \\
\text { code }\end{array}$} & \multicolumn{5}{|c|}{ Writhing count } & \multirow{2}{*}{$\begin{array}{l}\text { Number of writhing } \\
(\text { Mean } \pm \text { SEM })^{\mathrm{a}}\end{array}$} & \multirow{2}{*}{$\begin{array}{c}\text { Writhing } \\
(\%)\end{array}$} & \multirow{2}{*}{$\begin{array}{c}\text { Inhibition } \\
(\%)\end{array}$} \\
\hline & M-1 & M-2 & M-3 & M-4 & M-5 & & & \\
\hline CS & 23 & 21 & 31 & 19 & 25 & $23.8 \pm 2.059 * * *$ & 100.00 & - \\
\hline SS & 2 & 1 & 3 & 4 & 1 & $2.2 \pm 0.583^{* * * *}$ & 9.24 & 90.76 \\
\hline $3 \mathrm{~A}-1\left(\mathrm{~d}_{1}\right)$ & 18 & 14 & 11 & 7 & 19 & $13.8 \pm 2.223^{* *}$ & 57.98 & 42.02 \\
\hline $3 \mathrm{~A}-1\left(\mathrm{~d}_{2}\right)$ & 10 & 10 & 5 & 19 & 4 & $9.6 \pm 2.657 * * *$ & 40.34 & 59.66 \\
\hline $3 \mathrm{~A}-2\left(\mathrm{~d}_{1}\right)$ & 10 & 4 & 6 & 9 & 6 & $7.0 \pm 1.095^{* * *}$ & 29.41 & 70.59 \\
\hline $3 \mathrm{~A}-2\left(\mathrm{~d}_{2}\right)$ & 11 & 10 & 5 & 7 & 4 & $7.4 \pm 1.364 * * *$ & 31.09 & 68.91 \\
\hline $3 \mathrm{~A}-3\left(\mathrm{~d}_{1}\right)$ & 2 & 3 & 2 & 1 & 6 & $2.8 \pm 0.860^{* * *}$ & 11.76 & 88.24 \\
\hline $3 \mathrm{~A}-3\left(\mathrm{~d}_{2}\right)$ & 7 & 15 & 10 & 6 & 9 & $9.4 \pm 1.568 * * *$ & 39.50 & 60.50 \\
\hline $3 \mathrm{~B}-1\left(\mathrm{~d}_{1}\right)$ & 1 & 4 & 3 & 5 & 6 & $3.8 \pm 0.860^{* * * *}$ & 15.97 & 84.03 \\
\hline $3 B-1\left(d_{2}\right)$ & 10 & 10 & 12 & 15 & 10 & $11.4 \pm 0.979 * * *$ & 47.90 & 52.10 \\
\hline $3 B-2\left(d_{1}\right)$ & 5 & 3 & 1 & 6 & 2 & $3.4 \pm 0.927 * * *$ & 14.29 & 85.71 \\
\hline $3 \mathrm{~B}-2\left(\mathrm{~d}_{2}\right)$ & 4 & 14 & 13 & 3 & 14 & $9.6 \pm 2.502 * * *$ & 40.34 & 59.66 \\
\hline
\end{tabular}

${ }^{a}$ Each value represents Mean \pm SEM, $(\mathrm{n}=5) ; * * * \mathrm{p}<0.001 ; * * \mathrm{p}<0.01 ; *_{\mathrm{p}}<0.01$ compared with control (One-way ANOVA followed by Dunnett's test); $\mathrm{CS}=$ Control sample; $\mathrm{SS}=$ Standard sample (Diclofenac, $50 \mathrm{mg} / \mathrm{kg}$ b.w.); $\left(\mathrm{d}_{1}\right)=$ Lower dose $\left(50 \mathrm{mg} / \mathrm{kg}\right.$ b.w.); $\left(\mathrm{d}_{2}\right)=$ Higher dose (100 mg/kg b.w.).

Statistical analysis. All values are expressed as the mean \pm standard error of the mean (SEM). The results were statistically analyzed by One Way Analysis of Variance (ANOVA) followed by Dunnett's test by using IBM SPSS Statistics 19 software. Here, $\mathrm{p}<0.05$ was considered to be statistically significant.

Screening for antioxidant activity. The synthesized compounds were assessed for in vitro antioxidant potential by DPPH free radical scavenging method described by Brand-Williams et $a l .{ }^{30}$ with minor modifications. In this method, DPPH (2,2-diphenyl-1-picrylhydrazyl) was utilized to assess the free radical scavenging activity of various compounds $^{31}$, and tert-butyl-1-hydroxytoluene (BHT), a potential antioxidant, was used as the positive control. Briefly, $2.0 \mathrm{ml}$ of methanol solution of the test samples prepared in different concentrations $(0.977,1.953,3.906,7.813,15.625$, $31.25,62.5,125,250$ and $500 \mu \mathrm{g} / \mathrm{ml}$ ) was mixed with
$3.0 \mathrm{ml}$ of a DPPH methanol solution $(20 \mu \mathrm{g} / \mathrm{ml})$. The solutions were kept for $30 \mathrm{~min}$ at room temperature in a dark place. Afterwards, the absorbance was measured at $517 \mathrm{~nm}$ against methanol as blank by using UV-Spectrophotometer. DPPH, consisting of an unstable free radical, traps any radicals produced by the test compounds resulting in a visible color change ranging from violet to pale yellow. This decolorization is indicative of the reducing or free radical scavenging ability of the compounds which is also specified by changes in absorbance of the solutions of different concentrations measured at 517 $\mathrm{nm}$. Inhibition of free radical DPPH in percent (I \%) was calculated using the following equation:

$$
(\mathrm{I} \%)=\left(1-\mathrm{A}_{\text {sample }} / \mathrm{A}_{\text {blank }}\right) \times 100
$$

Where, $A_{\text {blank }}$ is the absorbance of control reaction (containing all reagents except the test materials) and $\mathrm{A}_{\text {sample }}$ is absorbance of sample.

The concentration of the compound providing $50 \%$ inhibition $\left(\mathrm{IC}_{50}\right)$ was calculated from the graph 
having the $\%$ inhibitions plotted against respective concentrations of the samples.

\section{RESULTS AND DISCUSSION}

The substituted benzimidazole derivatives were synthesized through the condensation of $o$ aryldiamine derivatives and aromatic aldehyde (Scheme 1). For the reaction, 1.0 equivalent of diamine compounds, (1A and $\mathbf{1 B})$ was allowed to condense with 3.0 equivalents of anisaldehyde (2) in the presence of ammonium chloride as a catalyst and chloroform as solvent. Based on temperature and reaction time (Table 1), five substituted benzimidazole derivatives identified as 2-(4Methoxyphenyl)-1H-benzimidazole (3A-1), 1-(4Methoxybenzyl)-2-(4-methoxyphenyl)-1H-benzimidazole (3A-2), 1-(4-Methoxybenzyl)-2-(4-methoxyphenyl)-3-(4-methoxybenzyl)-1H-benzimidazole

(3A-3), 2-(4-Methoxyphenyl)-4-methyl-1H-benzimidazole (3B-1) and 1-(4-Methoxybenzyl)-2-(4methoxyphenyl)-4-methyl-1H-benzimidazole (3B-2) were obtained. The synthesis of substituted benzimidazole derivatives has been reported in some previous studies, however, in different reaction conditions. ${ }^{32-36}$ Some of these reactions involved the use of expensive catalysts and high temperature. ${ }^{34-37}$ In order to overcome these limitations and identify the most suitable condition for obtaining higher yields of substituted benzimidazoles, we employed a simple condensation reaction with minor modification of a previously reported method. ${ }^{26}$ The reaction involved ammonium chloride, an inexpensive, commercially available and environment-friendly catalyst. Apart from minimizing the overall production cost, the reagent also contributed to the individual yield of our products.

The reaction of $o$-phenylenediamine $(\mathbf{1 A})$ with anisaldehyde produced a mixture of compounds $\mathbf{3 A}$ 1, 3A-2 and 3A-3 in 15, 35 and $25 \%$ yield respectively (total yield 70\%). The mono-, di- and trisubstituted derivatives, named $\mathbf{3 A - 1} \mathbf{1}^{26,33,35}, \mathbf{3 A - \mathbf { 2 } ^ { 3 4 - }}$ 37 and $\mathbf{3 A -} \mathbf{3}^{38}$ respectively, have been reported in the literature. On the other hand, the reaction between 2,3-diaminotoluene (1B) and anisaldehyde resulted in the formation of compounds $\mathbf{3 B - 1}$ and $\mathbf{3 B}-\mathbf{2}$ with 40 and $35 \%$ individual yield respectively (total yield $75 \%)$. The monosubstituted derivative $\mathbf{3 B}-\mathbf{1}^{39,40}$ and the disubstituted derivative $\mathbf{3 B}-\mathbf{2}^{40}$ were reported in previous studies. Unlike the first reaction, the trisubstituted compound could not be identified from the reaction between $\mathbf{1 B}$ and anisaldehyde. The possible reason behind the lack of formation of trisubstituted derivative might be the presence of a $\mathrm{CH}_{3}$ group at 4-position of benzimidazole moiety which extended steric hindrance to the upcoming functional group at 3-position. All the compounds were characterized by careful analyses of their IR and ${ }^{1} \mathrm{H}$ NMR spectral data. The IR spectrum of benzimidazole derivatives displayed stretching bands of aromatic and aliphatic rings in the regions of 3462$3053 \mathrm{~cm}^{-1}$ and $2964-2962 \mathrm{~cm}^{-1}$, respectively. The $\mathrm{C}=\mathrm{N}$ signals were observed for compounds $\mathbf{3 A - 1}$, 3A-2 and 3B-1 at 1631-1608 $\mathrm{cm}^{-1}$. Further stretching vibrations $\left(\mathrm{C}=\mathrm{C}, \mathrm{C}-\mathrm{N},-\mathrm{OCH}_{3}\right)$ were detected at $1513-1435 \mathrm{~cm}^{-1}, 1261-1244 \mathrm{~cm}^{-1}$ and $1179-1024 \mathrm{~cm}^{-1}$ respectively. In ${ }^{1} \mathrm{H}$ NMR spectra of disubstituted products 3A-2 and 3B-2, the protons of two $-\mathrm{OCH}_{3}$ groups showed two singlets at $\delta 3.80, \delta 3.90$ and $\delta$ $3.75, \delta 3.85$ respectively, and doublet and multiplets were seen in between $\delta$ 6.85-7.85 and 6.70-7.60, which indicated 12 and 11 aromatic protons of phenyl ring respectively. The formation of trisubstituted $\mathbf{3 A - 3}$ can be explained by three singlets for three $-\mathrm{OCH}_{3}$ groups at $\delta 3.78, \delta 3.83$ and $\delta 3.88$, and 16 aromatic protons in between $\delta 6.85-8.00$ in the NMR spectrum.

In the evaluation of peripheral analgesic activity, all the synthesized benzimidazole derivatives reduced the number of acetic acid-induced abnormal constrictions or writhings in mice. Statistical evaluation of the data $(p<0.001)$ demonstrated that the compounds $\mathbf{3 A - 3}, \mathbf{3 B}-\mathbf{1}$ and $\mathbf{3 B}-\mathbf{2}$ depicted encouraging analgesic property (\% of inhibition $88.24,84.03$ and 85.71, respectively) at a dose of 50 $\mathrm{mg} / \mathrm{kg}$ compared to that obtained by standard diclofenac (\% of inhibition 90.76). The synthesized compounds 3A-3, 3B-1 and 3B-2 at a dose 100 $\mathrm{mg} / \mathrm{kg}$ (\% of inhibition 60.50, 52.10 and 59.66 
respectively) and other derivatives at doses of both $50 \mathrm{mg} / \mathrm{kg}$ and $100 \mathrm{mg} / \mathrm{kg}$ showed moderate analgesic activity. The results are summarized in Table 2 and Figure 1.

The acetic acid promoted abdominal constriction response is a sensitive technique to establish nociception or pain in test animals. The response primarily involves the secretion of cytokines, such as tumor necrosis factor $\alpha$ (TNF- $\alpha$ ), interleukin $1 \beta$ (IL$1 \beta)$ and interleukin 8 (IL-8) by the local peritoneal macrophages and mast cells and is controlled by the prostaglandin pathways. ${ }^{41}$ The standard diclofenac used in our experiment is a nonsteroidal antiinflammatory drug (NSAID), which blocks the prostaglandin synthesis by inhibiting cyclooxygenase (COX) enzyme, precisely $\mathrm{COX}-2$ and produces antinociceptive action. ${ }^{42}$ Since the antinociceptive activity of our synthesized benzimidazole derivatives was comparable to that of diclofenac, they are likely to contain analgesic components capable of interfering with the prostaglandin pathways. Hence, the compounds bear the potential to be developed into NSAIDs and used in pain relief.

Analgesic activity of the synthesized benzimidazole derivatives

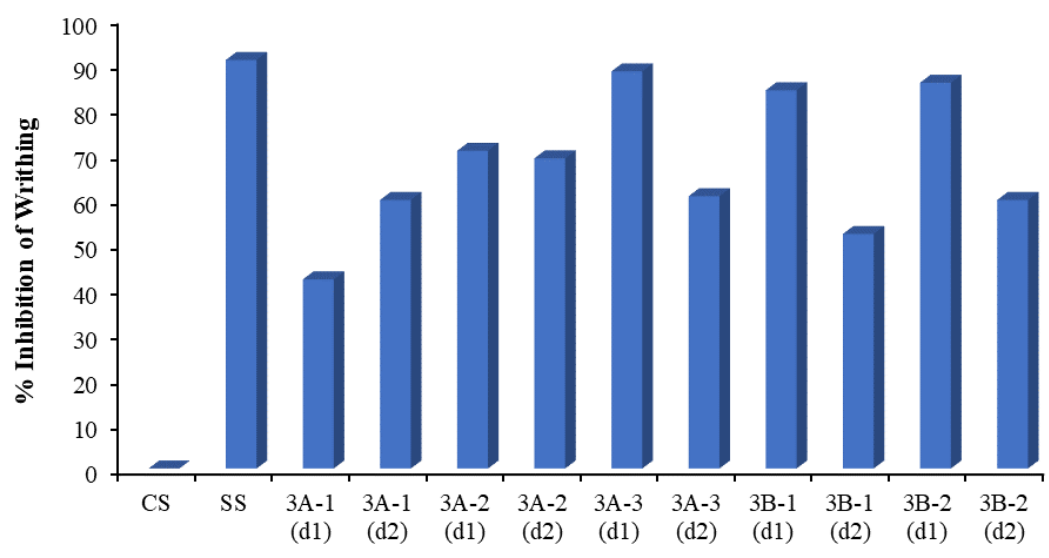

Tested Compounds

Figure 1. Peripheral analgesic activity of benzimidazole derivatives. CS: Control sample; SS: Standard sample (Diclofenac, $50 \mathrm{mg} / \mathrm{kg} \mathrm{b.w.);}$ (d1): Lower dose (50 mg/kg b.w.); (d2): Higher dose (100 mg/kg b.w.).

Table 3. Screening of antioxidant activity of benzimidazole derivatives by DPPH free radical scavenging method.

\begin{tabular}{|c|c|c|c|c|c|c|c|c|c|c|c|}
\hline \multirow[t]{2}{*}{ Sample } & \multicolumn{10}{|c|}{ Inhibition of DPPH free radical at different concentrations (\%) } & \multirow{2}{*}{$\begin{array}{c}\mathrm{IC}_{50} \\
\text { value } \\
(\mu \mathrm{g} / \mathrm{ml})\end{array}$} \\
\hline & $\begin{array}{c}0.977 \\
\mu \mathrm{g} / \mathrm{ml}\end{array}$ & $\begin{array}{l}1.953 \\
\mu \mathrm{g} / \mathrm{ml}\end{array}$ & $\begin{array}{c}3.906 \\
\mu \mathrm{g} / \mathrm{ml}\end{array}$ & $\begin{array}{c}7.813 \\
\mu \mathrm{g} / \mathrm{ml}\end{array}$ & $\begin{array}{l}15.625 \\
\mu \mathrm{g} / \mathrm{ml}\end{array}$ & $\begin{array}{l}31.25 \\
\mu \mathrm{g} / \mathrm{ml}\end{array}$ & $\begin{array}{c}62.5 \\
\mu \mathrm{g} / \mathrm{ml}\end{array}$ & $\begin{array}{c}125 \\
\mu \mathrm{g} / \mathrm{ml}\end{array}$ & $\begin{array}{c}250 \\
\mu \mathrm{g} / \mathrm{ml}\end{array}$ & $\begin{array}{c}500 \\
\mu \mathrm{g} / \mathrm{ml}\end{array}$ & \\
\hline BHT & 13.16 & 14.74 & 17.63 & 22.89 & 43.95 & 93.95 & 94.47 & 83.42 & 90.79 & 94.05 & 14.44 \\
\hline $3 \mathrm{~A}-1$ & 65.26 & 68.42 & 69.74 & 77.63 & 79.74 & 82.89 & 87.63 & 90.26 & 91.05 & 93.68 & 0.038 \\
\hline $3 \mathrm{~A}-2$ & 27.63 & 43.42 & 80.00 & 85.79 & 82.39 & 83.68 & 84.74 & 86.84 & 88.95 & 92.11 & 0.959 \\
\hline $3 \mathrm{~A}-3$ & 40.53 & 42.11 & 43.68 & 48.42 & 51.58 & 54.74 & 60.53 & 65.26 & 69.47 & 77.89 & 8.834 \\
\hline 3B-1 & 18.16 & 20.79 & 21.58 & 26.05 & 30.26 & 32.11 & 33.94 & 41.32 & 48.68 & 66.32 & 254.29 \\
\hline $3 B-2$ & 41.57 & 43.42 & 46.05 & 48.68 & 52.63 & 54.47 & 59.47 & 65.79 & 72.63 & 78.16 & 7.519 \\
\hline
\end{tabular}

In the evaluation of antioxidant property, compounds 3A-1, 3A-2, 3A-3 and 3B-2 produced superior results than the standard $\mathrm{BHT}\left(\mathrm{IC}_{50}=14.44\right.$ $\mu \mathrm{g} / \mathrm{ml}$ ) which is evident from their $\mathrm{IC}_{50}$ values $(0.038,0.959,8.834$ and $7.519 \mu \mathrm{g} / \mathrm{ml}$ respectively).
The derivatives 3B-1 had mild free radical scavenging activity compared to the standard. The results of the antioxidant activity of the compounds are summarized in Table 3. 
The $p$-methoxybenzyl group present on imidazole nitrogen of 3A-2, 3A-3 and 3B-2 might contribute to the improved antioxidant potential of these compounds compared to the standard and they emerged as the most promising antioxidant agents. The extended resonance produced by the radical formed from the benzyl group during the reaction may help in enhancing DPPH scavenging ability of the compounds. ${ }^{43}$

\section{CONCLUSIONS}

A simple, easy, and cost-effective method has been described for the synthesis of various substituted benzimidazole derivatives from two different diamine compounds and anisaldehyde with significant yields in the range of $70-75 \%$. To the best of our knowledge, this is the first report of antioxidant and analgesic properties of the synthesized derivatives among which compounds 3A-3 and 3B-2 showed the most encouraging results. The presence of $p$-methoxy benzyl substituent appeared to be beneficial for their biological activities. We assume these derivatives as potential lead compounds to design and develop novel, safe and potent antioxidant and analgesic agents.

\section{CONFLICT OF INTEREST}

The authors declare that they do not have any conflict of interest.

\section{AUTHORS' CONTRIBUTIONS}

SMAR designed the experimental work and supervised all the research activities. SRB performed the synthesis work. ZAM and SRB designed and performed the experiments with laboratory animals and analyzed the experimental data. PS carried out the rest of the work related to biological evaluation. SRB and PS performed the literature survey and wrote the manuscript.

\section{ACKNOWLEDGEMENTS}

The authors are utterly grateful to Jahangirnagar University, Bangladesh for providing laboratory animals and to the Institute of Nutrition and Food Science (INFS), University of Dhaka, Bangladesh for animal husbandry throughout the research. The first author expresses her gratitude to the Ministry of Science and Technology, Government of the People's Republic of Bangladesh for providing financial support through the National Science and Technology (NST) Fellowship (Fellowship No. 39.012.002.01.03.019.2013-282 [208]).

\section{REFERENCES}

1. El Rashedy, A.A. and Aboul-Enein, H.Y. 2013. Benzimidazole derivatives as potential anticancer agents. Mini Rev. Med. Chem. 13, 399-407.

2. Singh, N., Pandurangan, A., Rana, K., Anand, P., Ahamad, A. and Tiwari, A.K. 2012. Benzimidazole: A short review of their antimicrobial activities. Int. Curr. Pharm. J. 1,110-118.

3. Bansal, Y. and Silakari, O. 2012. The therapeutic journey of benzimidazoles: a review. Bioorg. Med. Chem. 20, 62086236

4. Shah, N.M. and Joshi, H.S. 2014. Synthesis and antimicrobial screening of some new pyrimido[1,2-a]benzimidazole derivatives. Int. Lett. Chem. Phys. Astron. 25, 56-60.

5. Zhang, X., Huang, Y., Harvey, P.R., Li, H., Ren, Y., Li, J., Wang, J. and Yang, H. 2013. Isolation and characterization of Carbendazim-degrading Rhodococcus erythropolis djl-11. PLoS One 8, e74810.

6. Leoni, L.M. 2011. Bendamustine: Rescue of an effective antineoplastic agent from the mid-twentieth century. Semin. Hematol. 48, S4-S11.

7. Spasov, A.A., Yozhitsa, I.N., Bugaeva, L.I. and Anisimova, V.A. 1999. Benzimidazole derivatives: spectrum of pharmacological activity and toxicological properties (a review). Pharm. Chem. J. 33, 232-243.

8. Meijer, D.K.F., Hovinga, G., Versluis, A., Bröring, J., van Aken, K., Moolenaar, F. and Wesseling, H. 1984. Pharmacokinetics of the oral narcotic analgesic bezitramide and preliminary observations on its effect on experimentally induced pain. Eur. J. Clin. Pharmacol. 27, 615-618.

9. Wienen, W., Entzeroth, M., van Meel, J.C.A., Stangier, J., Busch, U., Ebner, T., Schmid, J., Lehmann, H., Matzek, K., Kempthorne-Rawson, J., Gladigau, V. and Hauel, N.H. 2006. A review on telmisartan: a novel, long-acting angiotensin iireceptor antagonist. Cardiovasc. Drug Rev. 18, 127-154.

10. Hauel, N.H., Nar, H., Priepke, H., Ries, U., Stassen, J-M. and Wienen, W. 2002. Structure-based design of novel potent nonpeptide thrombin inhibitors. J. Med. Chem. 45, 17571766.

11. Barot, K.P., Nikolova, S., Ivanov, I. and Ghate, M.D. 2013. Novel research strategies of benzimidazole derivatives: a review. Mini Rev. Med. Chem. 13, 1421-1447. 
12. Kitzen, J.M. and Winbury, M.M. 1988. Pimobendan. Cardiovasc. Drug Rev. 6, 265-291.

13. Boyle, K.L. and Leech, E. 2012. A review of the pharmacology and clinical uses of pimobendan. J. Vet. Emerg. Crit. Care. 22, 398-408.

14. Singh, J., Grover, P. and Pathak, D.P. 2010. Synthesis, anticonvulsant activity and comparative QSAR study of some novel 1,2,5-trisubstituted benzimidazole derivatives. Acta Pharm. Sci. 52, 511-522.

15. Shah, K., Chhabra, S., Shrivastava, S.K. and Mishra, P. 2013. Benzimidazole: a promising pharmacophore. Med. Chem. Res. 22, 5077-5104.

16. Gaba, M. and Chander, M. 2015. Design, synthesis and biological evaluation of novel 1,2,5-substituted benzimidazole derivatives as gastroprotective antiinflammatory and analgesic agents. Med. Chem. 5, 58-63.

17. Yang, H., Ren, Y., Gao, X. and Gao, Y. 2016. Synthesis and anticoagulant bioactivity evaluation of 1,2,5-trisubstituted benzimidazole fluorinated derivatives. Chem. Res. Chin. Univ. 32, 973-978.

18. Ansari, K.F. and Lal, C. 2009. Synthesis, physicochemical properties and antimicrobial activity of some new benzimidazole derivatives. Eur. J. Med. Chem. 44, 40284033.

19. Walia, R., Hedaitullah, M., Naaz, S.F., Iqbal, K. and Lamba, H.S. 2011. Benzimidazole derivatives - an overview. Int. J. Res. Pharm. Chem. 1, 565-574.

20. Srivastava, S., Pandeya, S.N., Yadav, M.K. and Singh, B.K. 2013. Synthesis and analgesic activity of novel derivatives of 1,2-substituted benzimidazoles. J. Chem. 2013, 1-6.

21. Ayhan-Kilcigil, G., Kus, C., Çoban, T., Can-Eke, B. and Iscan, M. 2004. Synthesis and Antioxidant properties of novel benzimidazole derivatives. J. Enzyme Inhib. Med. Chem. 19, 129-135.

22. Ayhan-Kilcigil, G., Kus, C., Özdamar, E., Can-Eke, B. and Iscan, M. 2007. Synthesis and antioxidant capacities of some new benzimidazole derivatives. Arch. Pharm. (Weinheim). 340, 607-611.

23. Zhou, B., Li, B., Yi, W., Bu, X. and Ma, L. 2013. Synthesis, antioxidant, and antimicrobial evaluation of some 2arylbenzimidazole derivatives. Bioorg. Med. Chem. Lett. 23, 3759-3763.

24. Gaba, M., Singh, D., Singh, S., Sharma, V. and Gaba, P. 2010. Synthesis and pharmacological evaluation of novel 5substituted-1-(phenylsulfonyl)-2-methylbenzimidazole derivatives as anti-inflammatory and analgesic agents. Eur. J. Med. Chem. 45, 2245-2249.

25. Gaba, M., Singh, S. and Mohan, C. 2014. Benzimidazole: An emerging scaffold for analgesic and anti-inflammatory agents. Eur. J. Med. Chem. 76, 494-505.

26. Nannapaneni, D.T., Gupta Atyam, V.S.S.S., Reddy, M.I. and Sarva, R.C. 2010. Synthesis, characterization, and biological evaluation of benzimidazole derivatives as potential anxiolytics. J. Young Pharm. 2, 273-279.
27. Whittle, B. 1964. The use of changes in capillary permeability in mice to distinguish between narcotic and nonnarcotic analgesics. Br. J. Pharmacol. Chemother. 22, 246-253.

28. Collier, H.O.J., Dinneen, L.C., Johnson, C.A. and Schneider, C. 1968. The abdominal constriction response and its suppression by analgesic drugs in the mouse. Br. J. Pharmacol. Chemother. 32, 295-310.

29. Saha, A., Masud, M.A., Bachar, S.C., Kundu, J.K., Datta, B.K., Nahar, L. and Sarker, S.D. 2007. The analgesic and anti-inflammatory activities of the extracts of Phyllanthus reticulatus. in mice model. Pharm. Biol. 45, 355-359.

30. Brand-Williams, W., Cuvelier, M.E. and Berset, C. 1995. Use of a free radical method to evaluate antioxidant activity. LWT - Food Sci. Technol. 28, 25-30.

31. Kedare, S.B. and Singh, R.P. 2011. Genesis and development of DPPH method of antioxidant assay. J. Food Sci. Technol. 48, 412-422.

32. Borhade, A.V., Tope, D.R. and Patil, D.R. 2012. An efficient synthesis of Benzimidazole by cyclization-oxidation processes using $\mathrm{Fe} / \mathrm{MgO}$ as a heterogeneous recyclable catalyst. J. Chem. Pharm. Res. 4, 2501-2506.

33. Mobinikhaledi, A., Hamta, A., Mehdi Kalhor, M. and Shariatzadeh, M. 2014. Simple synthesis and biological evaluation of some benzimidazoles using sodium hexafluroaluminate, $\mathrm{Na}_{3} \mathrm{AlF}_{6}$, as an efficient catalyst. Iran. $J$. Pharm. Res. 13, 95-101.

34. Sharma, S.D. and Konwar, D. 2009. Practical, ecofriendly, and chemoselective method for the synthesis of 2-aryl-1arylmethyl- $1 h$-benzimidazoles using amberlite IR-120 as a reusable heterogeneous catalyst in aqueous media. Synth. Commun. 39, 980-991.

35. Azarifar, D., Pirhayati, M., Maleki, B., Sanginabadi, M. and Yami, R.N. 2010. Acetic acid-promoted condensation of $o$ phenylenediamine with aldehydes into 2-aryl-1-(arylmethyl)$1 H$-benzimidazoles under microwave irradiation. J. Serbian Chem. Soc. 75, 1181-1189.

36. Mohammadizadeh, M.R. and Taghavi, S.Z. 2011. Trifluoroacetic acid as an efficient catalyst for the room temperature synthesis of 2-aryl-1-arylmethyl-1 $h-1,3-$ benzimidazoles in aqueous media. E-Journal Chem. 8,101106.

37. Qian, K., Nian, X., Zhu, G.M., Cui, D.M. and Zhang, C. 2015. Nano $\mathrm{ZnO}$ catalyzed one-pot synthesis of benzimidazoles from $o$-phenylenediamine with aldehydes. Asian J. Chem. 27, 4045-4048.

38. Henkensmeier, D., Cho, H-R., Kim, H-J., Kirchner, C.N., Leppin, J., Dyck, A., Jang, J.H., Cho, E., Nama, S-W. and Lim, T-H. 2012. Polybenzimidazolium hydroxides structure, stability and degradation. Polym. Degrad. Stab. 97, 264-272.

39. Taha, M., Ismail, N.H., Imran, S., Mohamad, M.H., Wadood, A., Rahim, F., Saad, S.M., Rehman, A.U. and Khan, K.M. 2016. Synthesis, $\alpha$-glucosidase inhibitory, cytotoxicity and docking studies of 2-aryl-7-methylbenzimidazoles. Bioorg. Chem. 65, 100-109. 
40. Rao, C.V.C., Veeranagaiah, V., Reddy, K.K. and Rao, N.V.S. 1980. ChemInform Abstract: condensation of 3-methyl-ophenylenediamine with aromatic aldehydes. Chemischer Informationsdienst 11(39).

41. Ribeiro, R.A., Vale, M.L., Thomazzi, S.M., Paschoalato, A.B.P., Poole. S., Ferreira, S.H. and Cunha, F.Q. 2000. Involvement of resident macrophages and mast cells in the writhing nociceptive response induced by zymosan and acetic acid in mice. Eur. J. Pharmacol. 387, 111-118.
42. Cashman, J.N. 1996. The mechanisms of action of NSAIDs in analgesia. Drugs 52, 13-23.

43. Bellam, M., Gundluru, M., Sarva, S., Chadive, S., Netala, V.R., Tartte, V. and Cirandur, S.R. 2017. Synthesis and antioxidant activity of some new $\mathrm{N}$-alkylated pyrazolecontaining benzimidazoles. Chem. Heterocycl. Compd. 53, 173-178. 